\title{
HUBUNGAN PEMBERIAN ASI EKSKLUSIF TERHADAP KEJADIAN BALITA STUNTING DI WILAYAH KERJA PUSKESMAS JATINANGOR
}

\author{
Fardila elba ${ }^{1)}$, Mega Putri ${ }^{2)}$ \\ ${ }^{1)}$ Departemen Ilmu Kesehatan Masyarakat, Fakultas Kedokteran, Universitas Padjadjaran \\ 2) Program Studi Diploma Kebidanan, Fakultas Kedokteran,Universitas Padjadjaran \\ ${ }^{1)}$ fardilaelba@yahoo.com \\ ${ }^{2)}$ Megaputriamalanda28@gmail.com
}

\begin{abstract}
Abstrak
Hasil riset studi kasus gizi balita Indonesia (SSGBI) 2019 mencatat bahwa jumlah balita stunting di Indonesia saat ini mencapai 27,67\%. ${ }^{1}$ Di Jawa Barat sendiri angka kejadian stunting yaitu 29,9\%, sedangkan di Kabupaten Sumedang angkanya masih cukup tinggi yaitu sebesar 36\%. di Puskesmas Jatinangor pada bulan Mei 2021, jumlah balita stunting tercatat sebanyak 100 balita dari 4438 jumlah balita secara keseluruhan. Wilayah kerja Puskesmas Jatinangor menjadi lokus balita stunting di Kabupaten Sumedang.

Tujuan penelitian ini adalah untuk mengetahui bagaimana hubungan pemberian ASI Eksklusif terhadap kejadian balita stunting di wilayah kerja Puskesmas Jatinangor.

Jenis penelitian ini adalah kuantitatif. Analisis yang digunakan univariat dan bivariat dengan jumlah sampel 100 balita stunting di wilayah kerja Puskesmas Jatinangor. Pengambilan sampel dengan total sampling. Pada penelitian ini digunakan data sekunder kunjungan rumah lokus intervensi stunting.

Hasil penelitian ini didapatkan pemberian ASI Eksklusif pada balita stunting sebanyak $80 \%$ dan tidak ASI Eksklusif sebanyak 20\%. Setelah diuji dengan statistik analisis bivariat terdapat hubungan pamberian ASI Eksklusif terhadap kejadian balita stunting di wilayah kerja Puskesmas Jatinangor. Karena pada penelitian ini menggunakan uji chi-square (nilai $p<0.05$ yaitu $p$ value 0.000 ) terdapat hubungan signifikan antara pemberian ASI Ekslusif dengan kejadian stunting,

Simpulan pada penelitian ini yaitu pemberian ASI Eksklusif memiliki hubungan yang signifikan dengan kejadian stunting pada balita.
\end{abstract}

Kata kunci: ASI Eksklusif, Balita, Stunting.

\begin{abstract}
The results of the 2019 Indonesian toddler nutrition case study (SSGBI) noted that the number of stunting toddlers in Indonesia currently reaches 27.67\%.1 In West Java alone the stunting incidence rate is 29.9\%, while in Sumedang Regency the figure is still quite high, namely 36\%. At the Jatinangor Health Center in May 2021, the number of stunting toddlers was recorded at 100 children from 4438 total children under five. The working area of the Jatinangor Health Center is the locus of stunting for toddlers in Sumedang Regency.

The purpose of this study was to find out how the relation between exclusive breastfeeding and the incidence of stunting under five in the Jatinangor Health Center working area.

This type of research is quantitative. The analysis used univariate and bivariate with a sample of 100 stunting toddlers in the Jatinangor Health Center working area. Sampling with total sampling. In this study, secondary data on the locus of stunting under five were used.

The results of this study obtained exclusive breastfeeding for stunting toddlers as much as $80 \%$ and not exclusive breastfeeding as much as 20\%. After being tested with bivariate


statistical analysis, there was a relation between exclusive breastfeeding and the incidence of stunting in toddlers in the Jatinangor Health Center working area. Because in this study using the chi-square test ( $p$ value $<0.05$, namely $p$ value 0.000) there is a significant relationship between exclusive breastfeeding and the incidence of stunting,

The conclusion in this study is that exclusive breastfeeding has a significant relationship with the incidence of stunting in toddlers.

Keywords: Exclusive Breastfeeding, Toddler, Stunting

\section{PENDAHULUAN}

Kejadian stunting merupakan salah satu masalah gizi yang dialami oleh balita di dunia saat ini dimana kondisi gagal tumbuh pada anak akibat kekurangan gizi kronis. Balita di katakan stunting jika pertumbuhan tinggi badan tidak sesuai grafik pertumbuhan standar dunia. ${ }^{2}$ Data prevalensi balita stunting menurut World Health Organization (WHO), Indonesia termasuk kedalam negara ketiga dengan prevalensi tertinggi di regional Asia Tenggara/ South-East Asia Regional (SEAR). Hasil riset studi kasus gizi balita Indonesia (SSGBI) 2019 mencatat bahwa jumlah balita stunting di Indonesia saat ini mencapai $27,67 \%{ }^{1}$

Di Jawa Barat sendiri angka kejadian stunting yaitu 29,9\%, sedangkan di Kabupaten Sumedang angkanya masih cukup tinggi yaitu sebesar 36\%. Berdasarkan Sekretariat Daerah Kabupaten Sumedang (2018) terdapat beberapa anak yang menderita stunting di Desa Jatinangor. ${ }^{3}$ Pada tahun 2021 jumlah stunting di Puskesmas Jatinangor tercatat sebanyak 100 balita dari 4438 jumlah balita secara keseluruhan. Wilayah kerja Puskesmas Jatinangor menjadi lokus balita stunting di Kabupaten Sumedang.
Sangat pendek atau stunting dimana zskor tinggi badan dibawah minus dua berdasarkan tinggi rata-rata anak menurut usia berdasarkan standar pertumbuhan anak menurut WHO. ${ }^{1}$ Stunting menyebabkan penurunan kemampuan kognitif dan motorik serta penurunan performa kerja. Perkembangan kognitif berdampingan dengan proses pertumbuhan secara genetik atau kematangan fisik anak. Pertumbuhan pada masa anak menjadi salah satu indikator status kesehatan di masa selanjutnya. Masa dua tahun pertama kehidupan merupakan masa yang sangat peka terhadap lingkungan dan masa ini berlangsung sangat singkat serta tidak dapat diulangi lagi, sehingga masa balita disebut sebagai masa emas atau masa kritis. ${ }^{2}$ Hasil identifikasi dan telaah beberapa artikel bahwa faktor risiko terjadinya stunting di negara berkembang salah satunya adalah pemberian ASI Eksklusif.

ASI merupakan asupan gizi yang akan membantu pertumbuhan dan perkembangan anak. Salah satu manfaat dari ASI Eksklusif ialah dapat mendukung pertumbuhan bayi terutama tinggi badan karena kalsium ASI lebih efisien diserap dibanding susu formula. ${ }^{4}$ Memberikan ASI eksklusif adalah tidak memberikan bayi 
JURNAL SEHAT MASADA VOLUME XV

makananan atau minuman lain. Makanan pertama dan utama bayi adalah ASI dimana karbohidrat dalam ASI berupa laktosa, yang kandungan lemaknya berupa polyunsaturated fatty acid (asam lemak tak jenuh ganda). Protein utama nya adalah lactalbumin yang mudah dicerna oleh pencernaan bayi. Promosi pemberian ASI Eksklusif selama 6 bulan dilanjutkan dengan pemberian makananan pendamping serta tetap memberikan ASI merupakan outline program UNICEF. Hal ini penting sebagai upaya pencegahan kejadian overweight dan stunting pada bayi dan balita. ${ }^{5}$

Bayi yang tidak mendapatkan ASI dengan cukup berarti cenderung memiliki asupan gizi yang kurang baik dan dapat menyebabkan kekurangan gizi salah satunya dapat menyebabkan stunting. Hal ini sejalan dengan penelitian sebelumya oleh Indrawati 2016 yang menyatakan bahwa terdapat hubungan yang signifikan antara perilaku pemberian ASI terhadap kejadian stunting. ${ }^{6}$

Berdasarkan uraian latar belakang di atas, penulis merasa tertarik untuk melakukan penelitian dengan judul "Hubungan Pemberian ASI Eksklusif Terhadap Kejadian Balita Stunting di Wilayah Kerja Puskesmas Jatinangor".

\section{METODE}

Jenis penelitian yang digunakan adalah secara kuantitatif. Analisis yang digunakan univariat dan bivariat. Penelitian ini bertujuan untuk mengetahui gambaran dan menghubungkan pemberian ASI Eksklusif Jurnal Penelitian Kesehatan STIKes Dharma Husada Bandung
ISSN : 1979-2344

terhadap kejadian balita stunting di Wilayah Kerja Puskesmas Jatinangor. Populasi berjumlah 4438 balita secara keseluruhan. Teknik pengambilan sampel menggunakan total sampling, yaitu pengambilan sampel balita yang mengalami stunting. Sampel yang digunakan sebanyak 100 balita stunting. Instrumen pada penelitian melalui data sekunder kunjungan rumah lokus intervensi stunting. Pengolahan data menggunakan analisis univariat bertujuan untuk menjelaskan atau mendeskripsikan karakteristik setiap variabel penelitian. Analisis bivariat dilakukan terhadap dua variabel yang di duga berhubungan atau berkorelasi. Analisis statistik menggunakan uji chi-square dengan bantuan SPSS versi 2.1

\section{HASIL}

Hasil penelitian ini berjumlah 100 balita stunting yang memenuhi kriteria inklusi. Data penelitian berupa data sekunder yang berasal dari buku register hasil pengisian kuisioner kunjungan rumah lokus intervensi stunting yang dilaksanakan oleh petugas puskesmas.

Penelitian ini telah disetujui oleh Komite Etik Penelitian Kesehatan Fakultas Kedokteran Universitas Padjadjaran No 620/UN6.KEP/EC/2021. 
Tabel 1 Distribusi Frekuensi Berdasarkan Karakteristik Balita Stunting

\begin{tabular}{lcc}
\hline \multirow{2}{*}{ Karakteristik Balita } & \multicolumn{2}{c}{ Stunting } \\
\cline { 2 - 3 } & $\mathbf{f}$ & $\mathbf{\%}$ \\
\hline Jenis Kelamin & & \\
\hline Laki-laki & 49 & 49 \\
\hline Perempuan & 51 & 51 \\
\hline Total & $\mathbf{1 0 0}$ & $\mathbf{1 0 0}$ \\
\hline Usia BAlita & & \\
\hline $12-<24$ bulan & $\mathbf{1 2}$ & $\mathbf{1 2}$ \\
\hline $24-<36$ bulan & $\mathbf{3 3}$ & $\mathbf{3 3}$ \\
\hline $36-<48$ bulan & $\mathbf{3 0}$ & $\mathbf{3 0}$ \\
\hline $38-<59$ bulan & $\mathbf{2 5}$ & $\mathbf{2 5}$ \\
\hline Total & $\mathbf{1 0 0}$ & $\mathbf{1 0 0}$ \\
\hline
\end{tabular}

Berdasarkan tabel diatas terlihat bahwa banyaknya balita stunting di lihat dari jenis kelamin adalah perempuan dengan jumlah 51 $(51 \%)$, sedangkan untuk jenis kelamin laki-laki sejumlah 49 (49\%). Berdasarkan usia, banyaknya usia balita yang mengalami stunting yaitu pada usia $24-<36$ bulan sebanyak 33 (33\%), usia 12-<24 sebanyak 12 (12\%), usia 36-<48 bulan sebanyak 30 (30\%), dan usia $38-<59$ bulan sebayak $25(25 \%)$.

Tabel 2 Distribusi frekuensi ASI Eksklusif Balita Stunting

\begin{tabular}{lcc}
\hline \multicolumn{1}{c}{ Pemberian } & \multicolumn{2}{c}{ Stunting } \\
\cline { 2 - 3 } ASI Eksklusif & f & \% \\
\hline ASI Eksklusif & 80 & 80 \\
\hline Tidak ASI Eksklusif & 20 & 20 \\
\hline Total & $\mathbf{1 0 0}$ & $\mathbf{1 0 0}$ \\
\hline
\end{tabular}

Pemberian ASI Eksklusif memperoleh hasil $80(80 \%)$, sedangkan untuk untuk pemberian ASI tidak Eksklusif memperoleh hasil 20 (20\%)
Tabel 3 Hubungan Pemberian ASI Eksklusif Terhadap Kejadian Stunting

\begin{tabular}{lccl}
\hline \multicolumn{1}{c}{ Pemberian } & \multicolumn{2}{c}{ Stunting } & \multirow{2}{*}{$\boldsymbol{\rho}$-Value } \\
\cline { 2 - 3 } \multicolumn{1}{c}{ ASI Eksklusif } & $\mathbf{f}$ & $\boldsymbol{\%}$ & \\
\hline ASI Eksklusif & 80 & 80 & \multirow{2}{*}{0.000} \\
\hline Tidak ASI Eksklusif & 20 & 20 & \\
\hline Total & $\mathbf{1 0 0}$ & $\mathbf{1 0 0}$ & \\
\hline
\end{tabular}

Berdasarkan tabel diatas menunjukan $80 \%$ balita stunting diberikan ASI Eksklusif dan $20 \%$ balita stunting tidak diberikan ASI Eksklusif. Berdasarkan Uji Chisquare ( $p=0.000)$ yang menunjukan bahwa terdapat hubungan yang bermakna antara pemberian ASI Eksklusif dengan kejadian stunting.

\section{PEMBAHASAN}

Stunting adalah kondisi dimana balita memiliki panjang atau tinggi badan yang kurang jika dibanding dengan umur. Kondisi ini diukur dengan panjang atau tinggi badan yang lebih dari minus dua standar deviasi median standar pertumbuhan anak dari WHO. ${ }^{7}$ Pertumbuhan ini di pengaruhi oleh dua faktor, faktor internal yaitu faktor genetik, dan faktor eksternal yaitu faktor lingkungan yang sangat menentukan tercapainya potensi bawaann. ${ }^{8}$ Apabila faktor ini tidak tercapai dengan baik maka akan menghasilkan pertumbuhan yang normal pada anak, sebaliknya apabila kedua faktor ini tidak tercapai dengan baik maka hal ini, akan menyebabkan pertumbuhan yang terhambat dan mengakibatkan stunting pada anak.

Stunting ditandai dengan terlambatnya pertumbuhan anak yang mengakibatkan 
JURNAL SEHAT MASADA VOLUME XV

kegagalan dalam mencapai tinggi badan yang normal dan sehat sesuai usia anak. Stunting merupakan kekurangan gizi kronis atau kegagalan pertumbuhan di masa lalu dan digunakan sebagai indikator jangka panjang. ${ }^{3}$

Stunting dapat didiagnosis melalui indeks antropometrik tinggi badan menurut umur yang mencerminkan pertumbuhan linier yang dicapai dengan indikasi kurang. ${ }^{9}$ Gizi jangka panjang, akibat dari gizi yang kurang. Stunting merupakan pertumbuhan linier yang gagal untuk mencapai potensi genetik akibat dari pola makan yang buruk dan penyakit. Stunting yang terjadi pada masa anak merupakan faktor resiko meningkatnya angka kematian, fungsi tubuh yang tidak seimbang dan kemampuan kognitif dan perkembangan motorik yang rendah. ${ }^{10}$

Berdasarkan tabel 1 diatas terlihat bahwa banyaknya balita stunting di lihat dari jenis kelamin adalah perempuan dengan jumlah 51 (51\%), sedangkan untuk jenis kelamin laki-laki sejumlah 49 (49\%). Penelitian ini sejalan dengan penelitian Erni (2016) menyatakan bahwa persentase anak stunting 6-24 bulan berjenis kelamin laki-laki tidak berbeda jauh dibandingkan dengan perempuan yaitu 17,40\%. Dan 19,80\%, atau laki-laki sebanyak 31 dan perempuan sebanyak $36 .^{11}$ Jenis kelamin baik anak perempuan dan laki-laki beresiko untuk menjadi stunting. Jenis kelamin hanya dibedakan untuk menentukan status gizi anak 6-24 bulan. ${ }^{11}$ Pada tahun pertama kehidupan, laki-laki lebih rentan terkena malnutrisi dari pada anak perempuan dimana tubuh laki-laki lebih besar dan lebih membutuhkan asupan nutrisi yang banyak, sehingga apabila tidak tercukupi dengan baik maka pertumbuhannya akan terhambat. Menurut budaya yang berkembang di bali terutama pedesaan, anak laki-laki sangat mendapatkan perhatian lebih besar termasuk asupan gizi dibanding anak perempuan. Kemungkinan hal tersebut dapat menyebabkan perbedaan hasil distribusi stunting pada penelitian ini, dengan penelitian serupa di daerah lain. ${ }^{12}$

Berdasarkan tabel 2, banyaknya usia balita yang mengalami stunting yaitu pada usia 24$<36$ bulan sebanyak 33 (33\%), usia 12-<24 sebanyak 12 (12\%), usia $36-<48$ bulan sebanyak 30 (30\%), dan usia 38-<59 bulan sebayak 25 (25\%). Berdasarkan usia, banyaknya usia balita yang mengalami stunting yaitu pada usia $24-<36$ bulan sebanyak 33 (33\%). Hal ini sejalan dengan penelitian Uliyanti, dkk (2017) bahwa prevalensi tertinggi yang menjadi faktor resiko stunting itu pada usia 24-36 bulan sebanyak 47 $(46,1) .{ }^{13}$ Penelitian lain menyatakan bahwa balita dengan stunting pada usia 6-12 bulan akan tetap mengalami stunting pada usia 3-4 tahun apabila tidak diberikan intervensi sejak dini. Berdasarkan usia balita bahwa usia diatas 2 tahun, menjadi resiko terjadinya stunting, karena kesulitannya anak mengejar pertumbuhan yang terlambat. Melambatnya kecepatan pertumbuhan ini tercermin dalam penurunan nafsu makan, padahal dalam masa ini anak-anak membutuhkan kalori dan zat gizi 
JURNAL SEHAT MASADA VOLUME XV

yang adekuat untuk memenuhi kebutuhan zat gizi bagi mereka. ${ }^{14}$

Berdasarkan tabel 3 pemberian ASI Eksklusif memperoleh hasil 80 (80\%), sedangkan untuk pemberian ASI tidak Eksklusif memperoleh hasil 20 (20\%), dengan nilai hasil uji chi square $<0.05$ ( $p$ value $=$ 0.000) sehingga dapat disimpulkan pemberian ASI Eksklusif memiliki hubungan yang signifikan dengan kejadian stunting pada balita. Penelitian ini sejalan dengan penelitian dengan Sr.Anita,dkk menyatakan bahwa sebanyak 66 responden yang tidak diberika ASI Eksklusif mengalami stunting, $\mathrm{OR}=61$ artinya balita yang tidak diberikan ASI Eksklusif berpeluang 61 kali lipat mengalami stunting dibandingkan balita yang diberi ASI Eksklusif. Kemudian, balita yang tidak diberikan ASI Eksklusif memiliki peluang $98 \%$ untuk mengalami stunting. ${ }^{15}$

Air Susu Ibu (ASI) merupakan air susu yang dihasilkan seorang ibu setelah melahirkan. ASI Eksklusif adalah pemberian ASI yang diberikan sejak bayi dilahirkan hingga usia bayi 6 bulan tanpa memberikan makanan atau minuman lainnya seperti susu formula, air putih, air jeruk kecuali vitamin dan obat. ${ }^{16}$ ASI mengandung enzim pencerna susu sehingga organ pencernaan pada bayi sangat mudah untuk mencerna dan menyerap ASI. Komposisi ASI dengan konsentrasi sesuai dengan pencernaan bayi akan membuat bayi tumbuh dengan badan yang seimbang. Seorang anak yang diberikan ASI Eksklusif mempunyai tumbuh kembang yang baik, hal ini karena di dalam ASI terdapat antibodi yang baik sehingga membuat anak tidak mudah sakit, selain itu ASI juga mengandung beberapa enzim dan hormone. ASI merupakan asupan gizi yang akan membantu pertumbuhan dan perkembangan anak. Salah satu manfaat dari ASI Eksklusif ialah dapat mendukung pertumbuhan bayi terutama tinggi badan karena kalsium ASI lebih efisien diserap dibanding susu formula. Dimana salah satu manfaat dari ASI Eksklusif ialah dapat mendukung pertumbuhan bayi terutama tinggi badan karena kalsium ASI lebih efisien diserap dibanding susu pengganti ASI. ${ }^{17}$

Pada ASI teradapat kolostrum yang mengandung kekebalan salah satunya IgA (Imunoglobin A) yakni sangat penting untuk membuat seseorang bayi terhindar dari infeksi. IgA yang sangat tinggi terdapat pada ASI yang mampu melumpuhkan bakteri pathogen Ecoli dan beberapa bakteri pada pencernaan lainnya. Kandungan lainnya dalam ASI ialah Decosahaxanoic Acid (DHA) dan Arachiodnic Acid (AA) yang sangat penting dalam menunjang pembentukan sel-sel pada otak secara optimal sehingga bisa menjamin pertumbuhan dan kecerdasan pada seorang anak. ${ }^{16}$ Pemberian ASI dan susu formula diberikan secara bersamaan dapat mengakibatkan bayi lebih rawan terkena penyakit karena susu formula tidak mengandung zat antibodi sebaik kandungan zat antibodi pada ASI. ${ }^{18}$

ASI merupakan asupan gizi yang akan membantu pertumbuhan dan perkembangan 
JURNAL SEHAT MASADA VOLUME XV

anak. Salah satu manfaat dari ASI Eksklusif ialah dapat mendukung pertumbuhan bayi terutama tinggi badan karena kalsium ASI lebih efisien dibanding susu formula. ASI Eksklusif bersifat protektif terhadap kejadian stunting, oleh karena itu ibu harus dan wajib memberikan ASI secara Eksklusif kepada bayi sampai bayi usia 6 bulan dan tetap memberikan ASI sampai bayi berumur 2 tahun untuk memenuhi kebutuhan gizi bayi. ${ }^{19}$

Memberikan ASI eksklusif adalah tidak memberikan bayi makananan atau minuman lain. Makanan pertama dan utama bayi adalah ASI dimana karbohidrat dalam ASI berupa laktosa, yang kandungan lemaknya berupa polyunsaturated fatty acid (asam lemak tak jenuh ganda). Protein utama nya adalah lactalbumin yang mudah dicerna oleh pencernaan bayi. Promosi pemberian ASI Eksklusif selama 6 bulan dilanjutkan dengan pemberian makananan pendamping serta tetap memberikan ASI merupakan outline program UNICEF. Hal ini penting sebagai upaya pencegahan kejadian overweight dan stunting pada bayi dan balita. ${ }^{20}$

Sehingga dapat disimpulkan bahwa pemberian ASI Eksklusif dengan kejadian balita stunting memiliki nilai signifikan $<0.05$ ( $p$ value $=0.000)$ sehingga pemberian ASI Eksklusif memiliki hubungan yang signifikan dengan kejadian stunting pada balita. Hasil penelitian ini sesuai dengan teori yang menyatakan bahwa pengaruh ASI Eksklusif terhadap perubahan status gizi pendek disebabkan oleh fungsi ASI sebagai anti- infeksi karena mengandung immunologlobin. Bayi yang mendapat ASI secara Eksklusif selama 6 bulan dapat meningkatkan kecerdasan, kekebalan, dan perkembangan anak, selain itu mencegah infeksi dan mengurangi resiko masalah gizi. ${ }^{21}$

\section{DAFTAR PUSTAKA}

1. WHO. World Health Organization. Reducing stunting in children: equity considerations for achieving the global targets 2025. 2018;

2. Sri H, Fanny A, Nenden NA. Pemberdayaan Kader Kesehatan Dalam Pencegahan Dan Penatalaksanaan Stunting Pada Anak Di Wilayah Kerja Jatinangor. 2018;7.

3. PKM FK UKI. Gambaran Prevalensi dan Karakteristik Balita dengan Stunting pada 10 Desa Kabupaten Sumedang Tahun 2018. 2018;

4. Kementrian Kesehatan Republik Indonesia. Hasil Utama Riset Kesehatan Dasar Tahun 2016. 2016;

5. Dwi Agista Larasati,dkk. Hubungan Antara Kehamilan Remaja dan Riwayat Pemberian ASI Dengan Kejadian Stunting Pada Balita Di Wilayah Kerja Puskesmas Pujon Kabupaten Malang. Research Study. Larasti, et al. Amerta Nutr.2018.

6. Lestari EF, Dwihestie LK. ASI Eksklusif Berhubungan Dengan Kejadian Stunting Pada Balita. Jurnal Ilmiah Stikes Kendal. 2020;10. 
JURNAL SEHAT MASADA VOLUME XV

7. Kemenkes RI. Topik utama situasi balita pendek (stunting) di indonesia. Buletin jendela pusat data dan informasi, Kementrian kesehatan RI. 2018;

8. Dr. Nurhaedar Jafar, Apt MK. Pertumbuhan Balita. Makalah Ilmiah. 2019;

9. Kurniawati E. Faktor Risiko Kejadian Stunting Pada Balita di Kabupaten Kerinci Provinsi Jambi. 2020;2.

10. W Y, dkk. Darurat Stunting dengan Melibatkan Keluarga. In: Darurat Stunting dengan Melibatkan Keluarga. 2019;1.

11. Erni Rukmana, Dodik Briawan, Ikeu Ekawati. Faktor Resiko Stunting Pada Anak Usia 6-24 Bulan Di Kota Bogor. Volume 12, Nomor 3. Bogor. 2016.

12. Ikatan Dokter Indonesia.2017

13. Uliyanti, dkk. Faktor Yang Berhubungan Dengan Kejadian Stunting Pada Balita Usia 24-59 Bulan. Volume 3, Nomor 2. Jurnal Vokasi Kesehatan. 2017.

14. Rizki Kurnia Illahi. Hubungan Pendapatan Keluarga, Berat Badan Lahir, Dan Panjang Badan Dengan Kejadian Stunting Balita 2459 Bulan Di Bangkalan. Volume 3, Nomor 1. Jurnal Manajemen Kesehatan. 2017.

15. Sr. Anita Sampe,dkk. Hubungan Pemberian ASI Eksklusif Dengan Kejadian Stunting Pada Balita. Volume 11 Nomor 1. Jurnal Ilmiah Kesehatan Sandi Husada. 2020.
16. Astuti EEL. Gambaran Faktor Resiko Kejadian Stunting Pada Balita Usia 24-59 Bulan Di Desa Karangsari Kabupaten Kulon Progo. Yogyakarta. 2019;

17. Sampe SA, SJMJ, Toban RC, Madi MA. Hubungan Pemberian ASI Eksklusif Dengan Kejadian Stunting Pada Balita. 2020;

18. F H, N N. Faktor Risiko Stunting Pada Anak Usia 6-23 Bulan di Kabupaten Jeneponto (Risk Factors of Stunting among Children Aged 6-23 Months in Jeneponto Regency). 2016;

19. Lidia Fitri. Hubungan BBLR Dan ASI Eksklusif Dengan Kejadian Stunting Di Puskesmas Lima Puluh Pekanbaru. Volume 3, Nomor 1. Jurnal Endurance.2018

20. Dwi Agista Larasati,dkk. Hubungan Antara Kehamilan Remaja dan Riwayat Pemberian ASI Dengan Kejadian Stunting Pada Balita Di Wilayah Kerja Puskesmas Pujon Kabupaten Malang. Research Study. Larasti, et al. Amerta Nutr.2018.

21. Sri Handayani, dkk. Hubungan Status ASI Eksklusif Dengan Kejadian Stunting Pada Batita Usia 24-36 Bulan Di Desa Watugajah Kabupaten Gunung Kidul. Volume 14, Nomor 4. Jurnal Medika Respati.2019. 